Rev. Bras. Saúde Prod. Anim., Salvador, v.16, n.3, p.606-616 jul./set.., 2015 http://www.rbspa.ufba.br ISSN 15199940

\title{
Chemical composition and fatty acid profile of meat from heifers finished on pasture supplemented with feed additives
}

\author{
Composição química e perfil de ácidos graxos da carne de novilhas terminadas em \\ pastagem suplementadas com aditivos alimentares
}

\author{
COMPARIN, Marco Aurélio Scarton ${ }^{1 *}$; MORAIS, Maria da Graça ${ }^{1}$; FERNANDES, \\ Henrique Jorge ${ }^{2}$; COELHO, Roberta Gomes ${ }^{1}$; COUTINHO, Marcelo Aranda da Silva ${ }^{1}$; \\ RIBEIRO, Caroline Bertholini ${ }^{1}$; MENEZES, Bruna Biava de ${ }^{1}$; ROCHA, Raizza Fátima \\ Abadia Tulux ${ }^{1}$
}

\footnotetext{
${ }^{1}$ Universidade Federal de Mato Grosso do Sul, Faculdade de Medicina Veterinária e Zootecnia, Programa de Pós-Graduação em Ciência Animal, Campo Grande, Mato Grosso do Sul, Brasil.

${ }^{2}$ Universidade Estadual de Mato Grosso do Sul, Faculdade de Medicina Veterinária e Zootecnia, Departamento de Zootecnia, Aquidauana, Mato Grosso do Sul, Brasil.

*Endereço para correspondência: mascvet@yahoo.com.br
}

\section{SUMMARY}

Food additives were used to improve meat characteristics of Brangus heifers supplemented on pasture daily $(0.32 \% \mathrm{LW})$. The treatments were: supplement (with no additives); calcareous seaweed flour (Lithothamnium calcareum) added to the supplement; vitamin E and organic selenium added to the supplement; protected fat added to the supplement; a subcutaneous application of vitamin $\mathrm{D}$ seven days before slaughter + supplement; and the association of vitamin E, organic selenium and protected fat added to the supplement + one subcutaneous dose of vitamin $\mathrm{D}$ seven days before slaughter. The animals were supplemented by $109.80 \pm 11,71$ days and were slaughtered when they reached approximately $337.95 \pm 20,56 \mathrm{~kg}$ of LW. The experimental design was completely randomized with six treatments and 25 repetitions. The Longissimus dorsi muscle's chemical composition did not differ between treatments $(\mathrm{P}>0.05)$. The use of seaweed flour, vitamin $\mathrm{D}$, protected fat and the association of additives has the potential to improve the concentration of some unsaturated fatty acids in the Brangus heifers' meat $(\mathrm{P}<0.05)$, but without improving the level of unsaturated fatty acids class. We conclude that the use of additives in heifers finished in the pasture/supplement system has no effect on the meat quality, but only, isolated outcomes, on the content of some fatty acids.

Keywords: antioxidants, conjugated linoleic acid, Lithothamnium calcareum, polyunsaturated fatty acids, protected fat

\section{RESUMO}

Os aditivos alimentares foram utilizados com o intuito de melhorar as características da carne de novilhas Brangus suplementadas a pasto $(0,32 \%$ PV). Os tratamentos foram: suplemento base (sem aditivos); farinha de algas calcárias (Lithothamnium calcareum) adicionada ao suplemento base; vitamina $\mathrm{E}$ e selênio orgânico adicionados ao suplemento base; gordura protegida adicionada ao suplemento base; uma aplicação por via subcutânea de vitamina $\mathrm{D}$ sete dias antes do abate + suplemento base; e uma associação de vitamina $E$, selênio orgânico e gordura protegida adicionados ao suplemento base + uma aplicação por via subcutânea de vitamina $\mathrm{D}$ sete dias antes do abate. Os animais foram suplementados por $109,80 \pm 11,71$ dias, quando foram abatidos ao alcançarem aproximadamente $337,95 \pm 20,56 \mathrm{~kg}$ de $\mathrm{PV}$. O delineamento experimental foi inteiramente casualizado, com seis tratamentos e 25 repetições. A composição centesimal do músculo Longissimus dorsi não diferiu entre os tratamentos $(\mathrm{P}>0,05)$. A utilização de farinha de algas calcárias, vitamina $\mathrm{D}$, gordura protegida e aditivos associados tem potencial de aumentar a concentração de alguns ácidos graxos insaturados da carne de novilhas Brangus $(\mathrm{P}<0,05)$, sem, no entanto, melhorar o teor total da classe de insaturados. Conclui-se que a utilização de aditivos alimentares em novilhas terminadas em sistema de suplementação a pasto não tem efeitos sobre a qualidade da 
Rev. Bras. Saúde Prod. Anim., Salvador, v.16, n.3, p.606-616 jul./set.., 2015 http://www.rbspa.ufba.br ISSN 15199940

carne, exceto, de maneira isolada, sobre o teor de alguns ácidos graxos avaliados.

Palavras-chave: ácido linoleico conjugado, ácidos graxos poli-insaturados, antioxidantes, gordura protegida, Lithothamnium calcareum

\section{INTRODUCTION}

Among the most studied parameters related to the quality of cattle meat is the profile of fatty acids due to the importance of red meat in the diet of consumers, who, in turn, are increasingly demanding about the quality of products, with a special concern about the attributes that may lead to some improvement associated with decreased risk to health and increased life expectancy (SCOLLAN et al., 2006).

Polyunsaturated fatty acids, such as those of the omega-3 series, are associated to the reduction in the incidence of cardiovascular diseases and the prevention and treatment of tumors (TAPIERO, 2002). Therefore, it is necessary increases the search by estrategies for enhance polyunsaturated fatty acids, especially omega-3, in meat from animals raised and finished on pasture, since this is the most prevalent production system in Brazil.

The manipulation of the diet of beef cattle on pasture with a view to producing healthier meat can be made by adding components called feed additives. The vitamin $\mathrm{E}$ and selenium is recognized to improve the antioxidant level in the meat (ZEOULA \& GERON, 2006), the use of minerals at high concentrations (ENGLE, 2011) and the addition of protected fat (OLIVEIRA et al., 2012) in the diet of ruminants may increase the meat concentration of polyunsaturated fatty acids.
However cattle have peculiar characteristics in their gastrointestinal tract, ruminal microorganisms can alter the composition of these additives, thus, the expected effect may also be changed. The polyunsaturated fatty acids that reach the rumen can be converted to saturated fatty acids by ruminal microbes, through a chemical process known as biohydrogenation (KOZLOSKI, 2009).

Due to the above, this work aimed at studying the implications of the use of food additives on the chemical composition and fatty acid profile of the meat of Brangus heifers supplemented on pasture.

\section{MATERIAL AND METHODS}

The experiment was conducted at the São Geraldo farm, located at the municipality of Terenos, Mato Grosso do Sul. One hundred and fifty two-yearold Brangus heifers, with approximately $278.93 \pm 16.09 \mathrm{~kg}$ live weight were used. The animals were divided into six groups and housed in paddocks of Brachiaria brizantha cv. Marandu with 49 acres each, with pasture rotation every 14 days. The trial lasted for 125 days. The batches received $1 \mathrm{~kg}$ of concentrate/animal/day, for $109.80 \pm$ 11.71 days on average, during the rainy season, from December 2009 to April 2010.

In February, grass samplings from the six paddocks were collected and the "comparative yield method" described by Haydock \& Shaw (1975) was used to evaluate the herbage mass per hectare. Pasture samples were also collected through simulated grazer for nutritional value assessment (EUCLIDES et al. 1992). 
Rev. Bras. Saúde Prod. Anim., Salvador, v.16, n.3, p.606-616 jul./set.., 2015 http://www.rbspa.ufba.br ISSN 15199940

Food and pasture samples were previously dried in a forced ventilation oven at $55^{\circ} \mathrm{C}$ for 96 hours, ground in a Wiley mill with a $1 \mathrm{~mm}$ sieve and later analyzed according to methods described by AOAC (1995) and Van Soest (1963) (Table 1).

The treatments were as follows: $1 \mathrm{~kg}$ of supplement/animal/day (with no additives) (CON); 10 grams of calcareous seaweed flour (Lithothamnium calcareum)/animal/day $+0.99 \mathrm{~kg}$ of supplement (SF); $1 \times 10^{3} \mathrm{IU}$ vitamin $\mathrm{E}+$ $0.6 \mathrm{ppm}$ of organic selenium added to $1 \mathrm{~kg}$ of supplement/animal/day (VE); 150 grams of protected fat $+0.85 \mathrm{~kg}$ of supplement/animal/day $(\mathrm{PF}) ; 1 \mathrm{~kg}$ of supplement/animal/day + a subcutaneous application of $6 \times 10^{6}$ IU vitamin $\mathrm{D}_{3}$ /animal seven days before slaughter (VD); and a combination of $1 \times 10^{3} \mathrm{IU}$ vitamin $\mathrm{E}+0.6 \mathrm{ppm}$ of organic selenium
+150 grams of protected fat $+0.85 \mathrm{~kg}$ of supplement/animal/day $+\mathrm{a}$ subcutaneous application of $6 \times 10^{6} \mathrm{IU}$ vitamin $\mathrm{D}_{3}$ /animal seven days before slaughter (MIX). It has been estimated that each animal had an average consumption of $1 \mathrm{~kg}$ of supplement per day.

The protected fat used (Megalac-E $($ ) is an additive rich in omega- 6 fatty acids, formed from soybean oil through a calcium salt saponification process, which gives protection to polyunsaturated fatty acids.

Slaughter occurred in a commercial slaughterhouse when the animals reached an average final weight of $337.95 \pm$ $20.56 \mathrm{~kg}$ LW. Six slaughters were performed in a 5-week period, so that in each procedure the same number of animals per treatment was slaughtered.

Table 1. Bromatological composition of feed and samples of grassland of Brachiaria brizantha cv. Marandu

\begin{tabular}{|c|c|c|c|c|}
\hline Composition (g/kg DM) & Pasture & Supplement & Protected Fat & L. calcareum \\
\hline Kg DM/ha & 3916,00 & - & - & - \\
\hline DM & 287,08 & 882,90 & 950,00 & 995,20 \\
\hline $\mathrm{CP}$ & 69,58 & 161,55 & - & - \\
\hline $\mathrm{EE}$ & 22,07 & 38,62 & 850,00 & - \\
\hline NDF & 788,73 & 261,03 & - & - \\
\hline $\mathrm{NDF}_{\mathrm{ap}}$ & 765,20 & 245,07 & - & - \\
\hline $\mathrm{ADF}$ & 423,03 & 97,63 & - & - \\
\hline Lignin & 51,22 & 45,82 & - & - \\
\hline MM & 58,73 & 30,10 & 150,00 & 953,45 \\
\hline Calcium & 3,90 & - & 102,00 & 250,00 \\
\hline Phosphorus & 1,28 & - & - & 0,28 \\
\hline $\mathrm{NFC}^{2}$ & 84,42 & 524,66 & - & - \\
\hline $\mathrm{TDN}^{3}$ & 525,47 & 759,43 & - & - \\
\hline
\end{tabular}

After carcass cooling, a section of the Longissimus dorsi muscle of the left half carcass, between the $9^{\text {th }}$ and $12^{\text {th }}$ ribs, was removed and then frozen.
From this striploin section, two $2.5 \mathrm{~cm}$ thick samples were removed from the $9^{\text {th }}$ rib to determine the meat's lipid profile and chemical composition. 
In the first striploin sample, the muscle was pre-dried in a forced ventilation oven at $75^{\circ} \mathrm{C}$ for 48 hours; then it was crushed in a Wiley-type mill $(1 \mathrm{~mm}$ sieves) to determine the meat's chemical composition according to the methodology described by AOAC (1995): dry matter (DM), crude protein $(\mathrm{CP})$, ether extract (EE), and mineral matter (MM).

The second $L$. dorsi sample was used to analyze the profile and content of fatty acids. The lipid extraction and methylation of fatty acids were performed using the technique by Hara \& Radin (1978) with modifications. Five grams of muscle tissue sample were weighed. A mixture of isopropanol/hexane (2:3) was added for the extraction of fatty acids.

For the methylation reaction of these fatty acids, about 40mg of the extracted lipids were weighed. The necessary solvents for the reaction were added (methyl acetate, sodium methoxide $30 \%$ in methanol) and finally an anhydrous oxalic acid solution. Thus, the samples of fatty acids esterified and ready for analysis by gas chromatography were obtained.

The separation and detection of fatty acids were performed by gas chromatography using a Thermo Trace Ultra gas chromatograph (GC) with a flame ionization detector (FID) on a fused silica capillary column $(100 \mathrm{~m} \times 0.25 \mathrm{~mm}$ ID, $0.20 \mu \mathrm{m}$ film) (Restek RTX $®-2330$, Bellefonte, PA, USA). The gas helium was used as a carrier at a flow rate of 1.5 $\mathrm{ml} / \mathrm{min}$.

The injection technique used was the split (ratio 20:1). Retention time data and the percentages of components were obtained using ChromQuest software, version 4.2.

The identification and quantification of fatty acids was performed comparing the retention time with the co-injection of fatty acids methyl esters of samples and standards. Measurements were performed by using SIGMA external standards. The individual fatty acids are expressed as weight percentage of total methyl esters. These analyzes were made at FAMEZ/UFMS (Laboratory for Feed Analysis).

The experimental design was completely randomized with six treatments and 25 replications per treatment. The results were submitted to analysis of variance, by using the PROC GLM of SAS version 9.2 software (SAS, 2009). In the analyses of variance, the number of days to slaughter was used as a covariate.

When significant effects of treatments were found, the averages of treatments with additives were compared to the average of the control treatment using the Dunnett's test at 5\% significance.

\section{RESULTS AND DISCUSSION}

The VE treatment did not change the composition of meat (Table 2), with the adopted level of selenium having no influence on the mineral matter of the meat of animals supplemented with this additive. The effects of using the additive are related to the greater stability of cell membranes (ZEOULA \& GERON, 2006), which does not necessarily improve their levels to the point of changing the concentration of mineral matter in the meat.

Because vitamin D impacts the metabolism and the absorption of calcium, supplementation with this additive could increase the concentration of this mineral in the meat and directly affect the content of mineral matter; however, this was not observed. Neither were significant differences observed in the chemical composition of the flesh of animals that 
Rev. Bras. Saúde Prod. Anim., Salvador, v.16, n.3, p.606-616 jul./set.., 2015 http://www.rbspa.ufba.br

received the combination of additives $(\mathrm{P}>0.05)$.

When using calcareous seaweed flour in beef cattle from extensive breeding schemes, Melo \& Moura (2009) did not evaluate their effects on the meat's chemical composition. For the reason that this compound is rich in highly available minerals, changes related to the meat's mineral matter could occur. However, the low amount used (10g/animal/day) probably did not enable an increase in the intestinal absorption of minerals capable of modifying the content of mineral matter in muscle tissues.

The protected fat had no effect on the meat's chemical composition (Table 2). The supply of 150 grams was not enough to produce a substantial increase in the amount of absorbed fatty acids, thus not favoring an increase in tissue deposition.

Table 2. Chemical composition of Longissimus dorsi muscle of Brangus heifers supplemented with different feed additives

\begin{tabular}{|c|c|c|c|c|c|c|c|c|}
\hline \multirow{2}{*}{ Components (g/100g) } & \multicolumn{6}{|c|}{ Treatment $^{1,2}$} & \multirow{2}{*}{ CV $(\%)$} & \multirow{2}{*}{ P Value } \\
\hline & $\mathrm{CON}$ & SF & $\mathrm{VE}$ & VD & $\mathrm{PF}$ & MIX & & \\
\hline Moistness & 75,13 & 75,73 & 75,43 & 75,32 & 75,48 & 75,07 & 1,79 & 0,546 \\
\hline Crude protein & 22,33 & 21,88 & 22,14 & 22,01 & 21,85 & 22,25 & 5,69 & 0,699 \\
\hline Ether extracts & 1,66 & 1,41 & 1,44 & 1,69 & 1,68 & 1,77 & 39,52 & 0,256 \\
\hline Mineral matter & 1,00 & 1,01 & 1,06 & 1,01 & 1,10 & 1,00 & 16,06 & 0,122 \\
\hline
\end{tabular}

${ }^{1} \mathrm{CON}=$ control; $\mathrm{SF}=$ seaweed flour; $\mathrm{VE}=$ vitamin $\mathrm{E}+$ organic selenium; $\mathrm{VD}=$ vitamin $\mathrm{D} ; \mathrm{PF}=$ protected fat; $\mathrm{MIX}=$ vitamin $\mathrm{E}+$ selenium + vitamin $\mathrm{D}+$ protected fat.

${ }^{2}$ Averages followed by "*" differ from the control treatment average through Dunnett's test at $5 \%$ significance.

The increase in the diet's energy density using this additive could provide an increased supply of lipids for digestion and absorption in the small intestine (HARVATINE \& ALLEN, 2006). This could induce greater tissue deposition of fatty acids in the form of triglycerides (intramuscular fat) with a consequent increase in the ether extract content (RIEGEL, 2012).

Pires et al. (2008) also found no changes in moisture content, crude protein, ether extract and mineral matter of Angus and Nellore steers (two years old) supplemented with 5\% DM of protected fat during 166 days of confinement.

Despite being a high-energy additive, it was not capable of altering the fat content in beef, even when used in higher quantities.

When feed additives are used in beef cattle in order to improve the quality of the meat, the determination of the fatty acid profile is essential to check if such additives alter the concentrations of fatty acids.

One of the additives used for this purpose was vitamin D. When used alone, it led to an increase in the concentration of linolenic acid, from 0.19 to $0.30 \mathrm{~g} / 100 \mathrm{~g}$, compared to the treatment with no additives (Table 3 ). Such effect was not observed by Baldin (2010) when using $7.5 \times 10^{6} \mathrm{IU}$ vitamin $\mathrm{D}_{3}$ /animal/day in the diet of confined Nellore and Limousin beef cattle for 10 days prior to slaughter. 
Rev. Bras. Saúde Prod. Anim., Salvador, v.16, n.3, p.606-616 jul./set.., 2015 http://www.rbspa.ufba.br ISSN 15199940

This additive appears to have had some antioxidant effect on the linolenic acid in the tissues. Such effect is not usually attributed to this vitamin. But recently some hypotheses (NEYESTANI, 2014) have been raised as to potential antioxidant effects of this vitamin. The effects ranged from the tissue reduction of species reactive to oxygen to increases in the level of glutathione peroxidase enzyme (DANILENKO \& STUDZINSKI, 2004).

Table 3. Fatty acid profile of the Longissimus dorsi muscle of Brangus heifers supplemented with different feed additives

\begin{tabular}{lcccccccc}
\hline \multirow{2}{*}{$\begin{array}{l}\text { Analysed fatty acids } \\
\text { (g/100g methylester) }\end{array}$} & \multicolumn{7}{c}{ Treatment } \\
\cline { 2 - 8 } & CON & SF & VE & VD & PF & MIX & CV (\%) & P Value \\
\hline C14:0 (myristic) & 2,99 & 2,55 & 2,88 & 2,90 & 3,13 & 2,73 & 25,74 & 0,099 \\
C14:1 (myristoleic) & 0,31 & 0,26 & 0,30 & 0,28 & 0,32 & 0,26 & 34,25 & 0,210 \\
C15:0 (pentadecanoic) & 0,26 & 0,23 & 0,18 & 0,26 & 0,18 & 0,27 & 80,76 & 0,312 \\
C16:0 (palmitic) & 26,41 & 26,05 & 26,82 & 27,14 & 27,58 & 25,19 & 11,85 & 0,113 \\
C16:1 (palmitoleic) & 1,37 & 1,36 & 1,49 & 1,48 & 1,41 & 1,22 & 16,45 & 0,118 \\
C17:0 (heptadecanoic) & 6,75 & 6,82 & 6,09 & 6,68 & $5,78^{*}$ & $5,66^{*}$ & 18,31 & $<0,001$ \\
C17:1 (cis-11-heptadecanoic) & 0,20 & 0,22 & 0,22 & 0,22 & 0,18 & 0,17 & 25,28 & $<0,001$ \\
C18:0 (stearic) & 20,46 & 18,30 & 19,50 & 18,41 & 17,82 & 20,38 & 24,29 & 0,202 \\
C18:1 cis9 (elaidic) & 38,23 & 40,29 & 38,50 & 39,10 & 39,44 & 39,72 & 10,98 & 0,552 \\
C18:2 cis 9 trans11 (CLA) & 0,21 & 0,16 & 0,21 & 0,16 & 0,15 & 0,20 & 67,25 & 0,303 \\
C18:2 cis 9,12 (linoleic) & 1,62 & 2,09 & 2,08 & 1,92 & $2,54 *$ & $2,58^{*}$ & 48,41 & $<0,010$ \\
C18:3 $n$-3 (linolenic) & 0,19 & $0,33^{*}$ & 0,27 & $0,30^{*}$ & 0,27 & 0,27 & 46,49 & $<0,010$ \\
C20:4 $n$-6 (arachidonic) & 1,00 & 1,32 & 1,46 & 1,17 & 1,19 & 1,35 & 60,16 & 0,313 \\
\hline
\end{tabular}

${ }^{1} \mathrm{CON}=$ control; $\mathrm{SF}=$ seaweed flour; $\mathrm{VE}=$ vitamin $\mathrm{E}+$ organic selenium; $\mathrm{VD}=$ vitamin $\mathrm{D} ; \mathrm{PF}=$ protected fat; $\mathrm{MIX}=$ vitamin $\mathrm{E}+$ selenium + vitamin $\mathrm{D}+$ protected fat.

${ }^{2}$ Averages followed by "*" differ from the control treatment average through Dunnett's test at $5 \%$ significance.

More recently, in vitro experiences showed the antioxidant properties of vitamin $\mathrm{D}$, and later it was determined that this vitamin induced upregulation of antioxidant effectors such as superoxide dismutase and glutathione peroxidase (NEYESTANI, 2014).

Improved fatty acid profile is also associated with tissue antioxidative capacity. This is due to the fact that polyunsaturated fatty acids are more susceptible to oxidation and rancidity because of their double bonds (BALDIN, 2010).

Thus, the dose of vitamin D used in the present study may have improved the tissues' antioxidant capacity, decreasing or inhibiting the oxidation of the double bonds of linolenic acid in the meat.

Vitamin E is recognized mainly for its inter- and intracellular antioxidant role in the tissues of living organisms (ZEOULA $\&$ GERON, 2006). It inhibits the natural peroxidation of polyunsaturated fatty acids in the lipid layers, eliminating free radicals generated during the reduction of molecular oxygen and the normal activity of oxidative enzymes (ZEOULA \& GERON, 2006).

Due to the above, vitamin E and organic selenium have been used as a supplement, in doses higher than the recommended ones, and added to the diet of beef cattle. But the improvements of this supplementation 
Rev. Bras. Saúde Prod. Anim., Salvador, v.16, n.3, p.606-616 jul./set.., 2015 http://www.rbspa.ufba.br

on the fatty acids of meat did not occur here (Table 3 ). This may be related to the amount of vitamin $\mathrm{E}$ and selenium in the diet, and the use of larger amounts may lead to positive results, as found upon the addition of vitamin D.

The use of protected fat alone altered the levels of certain fatty acids. There was a 57\% increase (from 1.62 to $2.54 \mathrm{~g} / 100 \mathrm{~g}$ ) in the concentration of linoleic acid compared to the control treatment, and a decrease of heptadecanoic acid $(5.78 \mathrm{~g} / 100 \mathrm{~g})$ compared to control $(6.75 \mathrm{~g} / 100 \mathrm{~g})$.

These results can be considered positive by increasing the participation of a polyunsaturated fatty acid in meat. Wood et al. (2003) mentioned that the recommendation of the United Kingdom's Ministry of Health is that the polyunsaturated/saturated relation remains above 0.40 .

These findings are corroborated by Oliveira et al. (2012). Who supplemented $4.5 \%$ protected fat for confined Nellore cattle. The authors reported a decrease of heptadecanoic acid from 0.76 to $0.69 \mathrm{~g} / 100 \mathrm{~g}$, and an increase of linoleic acid from 5.66 to $7.82 \mathrm{~g} / 100 \mathrm{~g}$ in the animals' meat.

Lower ruminal biohydrogenation may lead to a change on the fatty acid profile of the digesta reaching the small intestine (ENGLE, 2011), leading to a lower participation of fatty acids of microbial origin, such as heptadecanoic acid, and consequently a greater amount of unsaturated fatty acids, in this case, linoleic acid. The odd-chain fatty acids are derived from the lipid membranes of rumen bacteria, since mammals are able to synthesize only fatty acids with an even number of carbons (FIEVEZ et al., 2003).

No studies have evaluated the influence of calcareous seaweed flour on the lipid profile of cattle meat. However, the result obtained in this study demonstrates that there is an effect of such additive on fatty acids of meat. Some studies (LEGLEITER et al., 2005; ENGLE, 2011) demonstrated that the addition of minerals such as copper and manganese to the diet of cattle can lead to the production of a meat with a healthier fatty acid profile.

Copper affects the metabolism of lipids and especially long chain fatty acids. Its deficiency results in elevated triglycerides, phospholipids, and cholesterol in blood serum (McDOWELL, 1992). Moreover, this element is associated to enzymes responsible for the decrease of free radicals and the oxidation of cell membranes, such as superoxide dismutase (BOZKAYA et al., 2001).

For the reason that Lithothamnium calcareum is basically composed of minerals, such as copper, some of these elements may have led to changes. Dias (2000) found primarily calcium carbonate and magnesium, besides over 20 trace elements such as $\mathrm{Fe}, \mathrm{Mn}, \mathrm{B}, \mathrm{Ni}$, $\mathrm{Cu}, \mathrm{Zn}, \mathrm{Mo}, \mathrm{Se}$ and $\mathrm{Sr}$, which show great bioavailability for intestinal absorption (MELO \& MOURA, 2009).

The calcareous seaweed flour treatment led to a $74 \%$ increase in the content of linolenic acid (C 18:3) as compared to control. This result is in agreement to those described by Correa et al. (2012), who observed some improvements in the levels of unsaturated fatty acids in meat from Nellore beef cattle supplemented with $10 \mathrm{mg}$ of organic copper per kg of dry matter/day.

According to Engle (2011), these effects could be caused by an inhibition in the rumen biohydrogenation. This process would be inhibited in its initial stage, in the formation of the isomer when the double bond is transferred in the form of trans to carbon-11 (KOZLOSKI, 2009). The mineral's ion would lead to the formation of an electronegative center 
Rev. Bras. Saúde Prod. Anim., Salvador, v.16, n.3, p.606-616 jul./set.., 2015 http://www.rbspa.ufba.br ISSN 15199940

in the hydrogen involved in the formation of the isomer (KEPLER et al., 1971), which would prevent the subsequent formation of single bonds in place of the double bonds.

This reaction would occur because the highly reducing potential of copper in rumen leads to a decrease in the reducing equivalents in the form of $\mathrm{NADH}$ and NADPH, which are responsible for the replacement of the double bonds (KOZLOSKI, 2009).

Copper is also involved in lipid metabolism, enhancing the activity of desaturase enzymes, which leads to an increased capacity of microsomal desaturation of adipocytes and liver cells and the consequent change in the fatty acid composition of deposited fat (ENGLE, 2011).

Because there are many minerals in the calcareous seaweed flour, the possible mechanisms involved in improving the fatty acid profile of meat are still unclear. Thus, they should be better explained by new research that considers both the effects on ruminal biohydrogenation and on lipid metabolism.

The treatment with associated additives (MIX) decreased $(\mathrm{P}<0.05)$ the contents of heptadecanoic acid (C 17:0) and increased $(\mathrm{P}<0.05)$ the levels of linoleic acid (C 18:2) compared to the control treatment. The decrease in the levels of heptadecanoic acid is described when protected fat is used in beef cattle, as well as an increase in the content of linoleic acid (OLIVEIRA et al., 2012).

When it provides diets rich in polyunsaturated fatty acids, such as in PF and MIX treatments, the meat tends to be richer in them, and a higher intake of vitamin $\mathrm{E}$ and selenium may reduce their oxidation and enable a more desirable profile of fatty acids (GOBERT et al., 2010), as occurred here.

The VD, VE and PF treatments were not different from control as to the classes of fatty acids and their relations, as shown in Table 4. The association of vitamin $\mathrm{D}$, protected fat, and vitamin $\mathrm{E}$ + selenium did not lead to desirable results, and no differences $(\mathrm{P}>0.05)$ were observed in any of the classes of fatty acids measured. Conversely, by using only protected fat in a larger quantity, Pires et al. (2008) and Gilbert et al. (2003) found a higher content of polyunsaturated fatty acids and observed improvement in the polyunsaturated/saturated ratio in steer meat.

Table 4. Relationship between groups of fatty acids of the Longissimus dorsi muscle of Brangus heifers supplemented with different feed additives

\begin{tabular}{lcccccccc}
\hline $\begin{array}{l}\text { Analysed fatty acids } \\
\text { (g/lo0g methylester) }\end{array}$ & CON & SF & VE & VD & PF & MIX & CV & P \\
(\%) & Value \\
\hline Saturated & 56,87 & 53,96 & 55,47 & 55,37 & 54,49 & 54,23 & 8,63 & 0,275 \\
Unsaturated & 43,13 & 46,04 & 44,53 & 44,63 & 45,51 & 45,77 & 10,57 & 0,274 \\
Monounsaturated & 40,11 & 42,14 & 40,51 & 41,07 & 41,35 & 41,37 & 10,60 & 0,645 \\
Polyunsaturated & 3,02 & 3,90 & 4,02 & 3,55 & 4,16 & 4,40 & 47,63 & 0,115 \\
Unsaturated: saturated & 0,769 & 0,869 & 0,816 & 0,824 & 0,846 & 0,855 & 19,37 & 0,296 \\
Monounsaturated: saturated & 0,714 & 0,795 & 0,742 & 0,758 & 0,768 & 0,772 & 18,98 & 0,455 \\
Polyunsaturated: saturated & 0,055 & 0,074 & 0,074 & 0,066 & 0,078 & 0,083 & 52,89 & 0,123 \\
\hline 'CON = control; SF = seaweed flour; VE = vitamin E + organic selenium; VD = vitamin D; PF = \\
protected fat; MIX = vitamin E + selenium + vitamin D + protected fat. \\
${ }^{2}$ Averages followed by "*" differ from the control treatment average through Dunnett's test at 5\% \\
significance.
\end{tabular}


Rev. Bras. Saúde Prod. Anim., Salvador, v.16, n.3, p.606-616 jul./set.., 2015 http://www.rbspa.ufba.br

The calcareous seaweed flour additive did not cause a significant decrease in saturated fatty acids class or an increase in unsaturated class, and there was no improvement in any of the fatty acid relations studied (Table 4).

By using a high amount of inorganic copper (10mg per $\mathrm{kg}$ of $\mathrm{DM}$ ) in confined Nellore cattle, Correa et al. (2012) observed a reduction of saturated fatty acids, from 50.19 to $45.10 \mathrm{~g} / 100 \mathrm{~g}$, and an increase of unsaturated class, from 49.81 to $54.90 \mathrm{~g} / 100 \mathrm{~g}$. Moreover, the unsaturated/saturated fatty acids ratio increased from 0.99 to $1.22 \mathrm{~g} / 100 \mathrm{~g}$, and the monounsaturated/saturated ratio increased from 0.88 to $1.11 \mathrm{~g} / 100 \mathrm{~g}$.

In the current study the additives showed positive effects on fatty acids, however such effects did not extend to classes of fatty acids or to the relations between them. This fact is probably related to the quantities used, since the existence of cause and effect is described in the papers cited above.

Both the use of seaweed flour and vitamin D (probable antioxidant effect) improved the linolenic acid content of meat, while the use of protected fat and associated additives (MIX $=$ vitamin $\mathrm{E}$ + selenium + vitamin $\mathrm{D}+$ protected fat) have the potential to improve the linoleic acid concentration in the meat of Brangus heifers.

Feed additives do not improvement the meat chemical composition. Furthermore, do not increase the concentration of classes of unsaturated, monounsaturated, and polyunsaturated fatty acids, or improve relations between the classes of unsaturated and saturated fatty acids in the meat of Brangus heifers finished in the pasture/supplement system.

\section{REFERENCES}

\section{ASSOCIATION OF OFFICIAL} ANALYTICAL CHEMISTRY AOAC. Official methods of analysis. 16. ed. Arlington, 1995. 1025p.

\section{BALDIN, S.R. Desempenho, características de carcaça e atributos da carne de bovinos jovens confinados suplementados com vitaminas D e E. 2010. 52f.} Dissertação (Mestrado em Zootecnia) Faculdade de Medicina Veterinária e Zootecnia, Universidade Estadual Paulista, Botucatu.

BOZKAYA, L.A. Effects of $\mathrm{Se}, \mathrm{Cu}$, and Se plus vitamin E deficiency on the activities of CuZnSOD, GSH-Px, CAT and LPO levels in Chicken Erythrocytes. Cell Biochemistry and Function, v.19, p.153-157, 2001.

CORREA, L.B.; DEL CLARO, G.R.; ZANETTI, M.A.; MELO, M.P.; ROSA, A.F.; SARAN NETTO, A. Effect of supplementation of two sources and two levels of copper on lipid metabolism in Nellore beef cattle. Meat Science, v.91, p.466-471, 2012.

DANILENKO, M.; STUDZINSKI, G.P. Enhancement by other compounds of the anti-cancer activity of vitamin D3 and its analogs. Experimental Cell Research, v.298, p.339-358, 2004.

DIAS, G.T.M. Granulados bioclásticos - Algas calcárias. Revista Brasileira de Geofísica, v.18, p.307-318, 2000.

ENGLE, T.E. Copper and lipid metabolism in beef cattle: a review.

Journal of Animal Science, v.89, p.591-596, 2011. 
Rev. Bras. Saúde Prod. Anim., Salvador, v.16, n.3, p.606-616 jul./set.., 2015 http://www.rbspa.ufba.br ISSN 15199940

EUCLIDES, V.P.B; MACEDO, M.C.M; OLIVEIRA, M.P. Avaliação de diferentes métodos de amostragem para se estimar o valor nutritivo de forragens sob pastejo. Revista Brasileira de Zootecnia, v.21, n.4, p. 691-702, 1992.

FIEVEZ, V.; VLAEMINCK, B.; DHANOA, M.S.; DEWHURST, R.J. Use of principal component analysis to investigate the origin of heptadecanoic and conjugated linoleic acids in milk.

Journal of Dairy Science, v.86, p.4047-4053, 2003.

GILBERT, C.D.; LUNT, D.K.; MILLER, R.K.; SMITH, S.B. Carcass, sensory, and adipose tissue traits of Brangus steers fed caseinformaldehyde-protected starch and/or canola lipid. Journal of Animal Science, v.81, p.2457-2468, 2003.

GOBERT, M.; GRUFFAT, D.; HABEANU, M.; PARAFITA, E.; BAUCHART, D.; DURAND, D. Plant extracts combined with vitamin $\mathrm{E}$ in PUFA-rich diets of cull cows protect processed beef against lipid oxidation. Meat Science, v.85, n.4, p.676-683, 2010.

HARA, A.; RADIN, N.S. Lipid extraction of tissues with low-toxicity solvent. Analytical Biochemistry, v.90, p.420-426, 1978.

HARVATINE, K.J.; ALLEN, M.S. Fat supplements affect fractional rates of ruminal fatty acid biohydrogenation and passage in dairy cows. Journal of Nutrition, v.136, p.677-685, 2006.

HAYDOCK, K.P.; SHAW, N.H. The comparative yield method for estimating dry matter yield of pasture. Australian Journal of Experimental Agriculture and Animal Husbandry, v.15, p.663-670, 1975.
KEPLER, C.R.; TOVE, S.B.; TUCKER, W.P. Biohydrogenation of unsaturated fatty acids. Stereospecificity of proton addition and mechanism of action of linoleic acid $\Delta$-cis, $\Delta$ transisomerase from Butyrivibrio fibrisolvens. Journal of Biololgy Chemistry, v.246, p.2765-2771, 1971.

KOZLOSKI, G.V. Bioquímica dos ruminantes. 2.ed. Santa Maria: Universiade Federal de Santta Maria, 2009. 44p.

LEGLEITER, L.R.; LLOYD, K.E.; SPEARS, J.W. Influence of dietary manganese on performance, lipid metabolism, and carcass composition of growing and finishing steers. Journal of Animal Science, v.83, p.2434-2439, 2005.

McDOWELL, LR. Minerals in animal and human nutrition. New York: Academic Press, 1992.

MELO, T.V.; MOURA, A.M.A. Utilização da farinha de algas calcárias na alimentação animal. Archivos de Zootecnia, v.58, p.99-107, 2009.

NEYESTANI, T.R. Vitamin D, oxidative stress and diabetes: Is there a link? In: PREEDY, V.R. (Ed.).

\section{Diabetes: Oxidative Stress and} Dietary Antioxidants. 1.ed. London: Academic Press in a imprint of Elsevier, 2014. 111p.

OLIVEIRA, E.A.; SAMPAIO, A.A.M.; HENRIQUE, W.; PIVARO, T.M.; ROSA, B.L.; FERNANDES, A.R.M.; ANDRADE, A.T. Quality traits and lipid composition of meat from Nellore young bulls fed with different oils either protected or unprotected from rumen degradation. Meat Science, v.90, p.2835, 2012. 
Rev. Bras. Saúde Prod. Anim., Salvador, v.16, n.3, p.606-616 jul./set.., 2015 http://www.rbspa.ufba.br ISSN 15199940

PIRES, I.S.C; ROSADO, G.P.; COSTA, N.M.B.; MONTEIRO, J.B.R.; OLIVEIRA, R.S.; JAEGER, S.M.P.L.; MOURÃO, D.M. Composição centesimal e perfil de ácidos graxos da carne de novilho precoce alimentado com lipídios protegidos. Ciência e Tecnologia de Alimentos, v.28, p.178183, 2008.

RIEGEL, R.E. Bioquímica. 5.ed. São Leopoldo: Unisinos, 2012. 197p.

STATISTICAL ANALYSIS SYSTEM - SAS. SAS user's guide: statistics. Version 9.2. Cary, NC: SAS Institute, 2009.

SCOLLAN, N.; HOCQUETTE, J.F.; NUERNBERG, K.;

DANNENBERGER, D.;

RICHARDSON, I; MOLONEY, A. Innovations in beef production systems that enhance the nutritional and health value of beef lipids and their relationship with meat quality. Meat Science, v.74, p.17-33, 2006.

TAPIERO, H. Polyunsaturated fatty acids and eicosanoids in human health and pathologies. Biomedicine and Pharmacotherapy, v.56, p.215-222, 2002.

VAN SOEST, P. J. Use of detergents in the analysis of fibrous feeds. II. A rapid method for the determination of fiber and lignin. Journal of the Association of Official Analytical Chemists, v.4, p.829-835, 1963.

WEISS, W.P. Energy prediction equations for ruminant feeds. In: CORNELL NUTRITION CONFERENCE FOR FEED MANUFACTURERS, 61., 1999, Ithaca. Proceedings... Ithaca: Cornell University, 1999. p.176-185.
WEISS, W.P.; CONRAD, H.R.; PIERRE, N.R. St. A theoretically-based model for predicting total digestible nutrient values of forages and concentrates. Animal Feed Science and Technology, v.39, p.95-110, 1992.

WOOD, J.D.; RICHARDSON, R.I.; NUTE, G.R.; FISHER, A.V.; CAMPO, M.M.; KASAPIDOU, E.; SHEARD, P.R.; ENSER, M. Effects of fatty acids on meat quality: a review. Meat Science, v.66, n.1, p.21-32, 2003.

ZEOULA, L.M.; GERON, L.J.V. Vitaminas. In: BERCHIELLI, T.T.; PIRES, A.V.; OLIVEIRA, S.G. (Eds.). Nutrição de ruminantes. 1.ed. Jaboticabal: Funep, 2006. p.367-371.

Data de recebimento: $16 / 03 / 2015$

Data de aprovação: 25/08/2015 